\title{
Layanan Bimbingan Konseling Dalam Meningkatkan Motivasi Belajar Peserta Didik di SMP Negeri 9 Kabupaten Musi Banyuasin Pada Masa Pandemi Covid-19
}

\author{
Mariati $^{1}$, M. Ferdiansyah ${ }^{2}$, Endang Surtiyoni ${ }^{3}$ \\ Universitas PGRI Palembang ${ }^{1}$ \\ Email: eliaja1414@gmail.com \\ Universitas PGRI Palembang ${ }^{2}$ \\ Email: mferdiansyah34@yahoo.com \\ Universitas PGRI Palembang ${ }^{3}$ \\ Email: surtyoniendang@gmail.com
}

\begin{abstract}
ABSTRAK
Pembelajaran daring yang telah dilakukan selama satu tahun menyebabkan pembelajaran menjadi lebih pasif dan peserta didik tidak termotivasi untuk belajar. Penelitian ini bertujuan untuk mengetahui proses layanan bimbingan konseling dalam meningkatkan motivasi belajar peserta didik di SMP Negeri 9 Kabupaten Musi Banyuasin pada masa pandemi covid-19. Penelitian yang dilakukan adalah penelitian lapangan (field research). Jenis penelitian yang digunakan adalah penelitian deskriptif kualitatif. Teknik pengumpulan data dalam penelitian ini adalah Observasi, Wawancara, dan Dokumentasi. Hasil penelitian dilakukan dengan pengamatan, triangulasi (sumber, cara dan waktu), dan diskusi dengan teman sejawat. Data yang diperoleh dianalisis dengan mengorganisasikan data, pengelolaan data dan mensintesiskannya dalam bentuk uraian dan gambaran tentang kondisi layanan bimbingan konseling dalam meningkatkan motivasi belajar peserta didik SMPN 9 Kabupaten Musi Banyuasin pada masa pandemi covid-19. Berdasarkan hasil penelitian, dapat disimpulkan bahwa layanan bimbingan konseling dalam meningkatkan motivasi belajar peserta didik di SMP Negeri 9 Kabupaten Musi Banyuasin pada masa pandemi covid-19 dalam pelaksanaannya sudah baik.
\end{abstract}

Kata Kunci: Layanan, Bimbingan Konseling, Motivasi Belajar, Pandemi, Covid-19

\section{Counseling Guidance Services in Increasing Students' Learning Motivation at SMP Negeri 9 Musi Banyuasin Regency During the Covid-19 Pandemic}

\begin{abstract}
Online learning that has been carried out for one year causes learning to be more passive and students are not motivated to learn. This study aims to determine the process of counseling guidance services in increasing students' learning motivation at Junior High School 9 Musi Banyuasin during the covid-19 pandemic. The research conducted is field research. The type of research used is descriptive qualitative research. Data collection techniques in this study are observation, interviews, and documentation. The validity of the research data was tested by observation, triangulation (source, method and time), and discussion
\end{abstract}


with colleagues. The data obtained were analyzed by organizing data, managing data and synthesizing it in the form of descriptions and descriptions of the condition of counseling guidance services in increasing the learning motivation of students at Junior High School 9 Musi Banyuasin during the covid-19 pandemic. Based on the results of the study, it can be concluded that the counseling service in increasing the learning motivation of students at Junior High School 9 Musi Banyuasin during the covid-19 pandemic has been implemented well.

Keywords: Services, Counseling Guidance, Learning Motivation, Pandemic, Covid-19

\section{PENDAHULUAN}

Pembelajaran daring di seluruh jenjang pendidikan masih terus dilakukan sebagai bentuk upaya mencegah penularan Covid-19 di lingkungan sekolah. Sejak bulan April 2020, pembelajaran daring di Kabupaten Musi Banyuasin telah terlaksana sesuai anjuran pemerintah pusat dan daerah. Awalnya, pemerintah pusat memberikan alternatif pembelajaran melalui stasiun TVRI untuk setiap jenjang pendidikan, baik sekolah dasar, sekolah menengah pertama hingga sekolah menengah atas, agar peserta didik tidak ketinggalan pelajaran yang seharusnya mereka peroleh di sekolah.

Pembelajaran daring yang telah dilakukan selama satu tahun menyebabkan peserta didik kurang aktif dalam pembelajaran sehingga mengakibatkan pembelajaran menjadi lebih pasif dan tidak termotivasi untuk belajar. Peserta didik yang tidak termotivasi dalam belajar dapat mengakibatkan turunnya hasil belajar di sekolah. Oleh karena itu, motivasi belajar peserta didik sangat diperlukan dalam proses pembelajaran daring dan luring. Semangat belajar dapat dimiliki peserta didik dengan cara meningkatkan motivasi belajar. Motivasi belajar dapat menggerakkan atau mendorong seseorang untuk belajar. Motivasi yang rendah dapat menyebabkan tidak optimalnya peserta didik dalam belajar sehingga prestasi belajar peserta didik dapat turun.

Lemahnya motivasi belajar peserta didik saat belajar dari rumah merupakan permasalahan yang muncul selama masa pandemi covid-19, baik bagi guru, orang tua maupun peserta didik. Banyak peserta didik yang tidak disiplin saat pembelajaran daring berlangsung.

Banyak peserta didik terlambat ketika pembelajaran daring berlangsung, orang tua kurang memperhatikan dan membimbing anaknya di rumah karena ada 
kewajiban lain yang harus dilakukan, masalah akses internet, peserta didik yang semakin sulit bangun pagi untuk mengikuti pembelajaran daring, dan sebagainya. Selama pembelajaran daring terdapat penurunan motivasi belajar peserta didik. Kendala lainnya yang muncul adalah minimnya kuota dan sinyal internet, walaupun Kementerian Pendidikan, Kebudayaan, Riset, dan Teknologi Republik Indonesia telah menyediakan kuota internet untuk guru dan peserta didik, tetapi tidak semua mendapatkan akses internet meski telah terdaftar di Data Pokok Pendidikan (Dapodik).

Berdasarkan hasil studi pendahuluan yang dilakukan pada bulan Desember 2020, diketahui selama pembelajaran daring dan luring, banyak peserta didik yang nilainya belum tuntas. Hasil pembelajaran memberikan gambaran bahwa kondisi hasil belajar peserta didik selama masa pandemi covid-19 di SMP Negeri 9 Kabupaten Musi Banyuasin pada semester ganjil tahun pelajaran 2020/2021 masih rendah. Sedangkan pada lingkungan keluarga, rata-rata latar belakang keluarga peserta didik kurang memperhatikan perkembangan belajar anaknya, hal ini disebabkan oleh kesibukan orang tua untuk mencari nafkah dan kesibukankesibukan lainnya, oleh sebab itulah orangtua kurang memperhatikan pendidikan anaknya di rumah. Hal ini menyebabkan kurangnya motivasi belajar peserta didik, sehingga mengakibatkan turunnya prestasi belajar.

Tujuan Penelitian ini adalah untuk mengetahui proses layanan bimbingan konseling dalam meningkatkan motivasi belajar peserta didik di SMP Negeri 9 Kabupaten Musi Banyuasin pada Masa Pandemi Covid-19.

Menurut George dan Cristiani dalam Awaliya (2013: 5), tujuan utama dari bimbingan konseling adalah: Menyediakan fasilitas untuk perubahan perilaku, Meningkatkan keterampilan untuk menghadapi sesuatu, Meningkatkan kemampuan dalam menentukan keputusan, Meningkatkan dalam hubungan antar perorangan, Menyediakan fasilitas pengembangan kemampuannya.

Layanan Bimbingan dan Konseling memiliki tujuh jenis layanan, yakni: layanan orientasi, layanan informasi, layanan penempatan dan penyaluran, layanan pembelajaran, layanan konseling perorangan, layanan bimbingan kelompok, layanan konseling kelompok, layanan konsultasi dan layanan mediasi. 
Motivasi belajar dapat timbul karena adanya faktor instrinsik dan ekstrinsik. Motivasi intrinsik adalah motif-motif yang menjadi aktif atau berfungsinya itu tidak perlu rangsangan dari luar, karena didalam diri setiap individu sudah ada dorongan untuk melakukan sesuatu. Sedangkan motivasi ekstrinsik adalah motif-motif yang aktif dan berfungsi karena adanya rangsangan dari luar. Oleh karena itu motivasi ekstrinsik adalah bentuk motivasi yang di dalamnya aktivitas belajar dimulai diteruskan berdasarkan dorongan dari luar yang tidak secara mutlak berkaitan dengan aktivitas belajar (Sardiman, 2012: 90).

Layanan bimbingan konseling dalam motivasi belajar ialah suatu kegiatan dalam bentuk pelayanan bantuan yang berlangsung melalui proses dengan permasalahan yang dirasakan oleh klien terkait dengan dorongan internal dan eksternal dalam belajar untuk diarahkan agar berkembang menjadi peserta didik yang mandiri, bertanggung jawab, kreatif, produktif, dan berlaku jujur.

\section{METODE PENELITIAN}

Penelitian ini berlokasi di SMP Negeri 9 Kabupaten Musi Banyuasin, Jl. Sekayu-Keluang KM.12 Desa Muara Teladan Kecamatan Sekayu Kabupaten Musi Banyuasin 30711. Penelitian dilakukan pada semester genap tahun pelajaran 2020-2021. Penelitian yang dilakukan adalah penelitian lapangan (field research). Penggunaan metode ini karena peneliti terjun langsung ke lapangan, terlibat dengan masyarakat setempat untuk mendapatkan gambaran yang lebih komprehensif tentang situasi setempat (Raco, 2010: 9). Penelitian ini merupakan penelitian kualitatif yakni suatu penelitian yang bertujuan untuk menerangkan fenomena sosial atau suatu peristiwa.

Sedangkan jenis penelitian yang digunakan adalah penelitian deskriptif kualitatif. Penelitian deskriptif adalah jenis penelitian yang memberikan gambaran atau uraian atas suatu keadaan sejelas mungkin tanpa ada perlakuan terhadap obyek yang diteliti (Kountoro, 2004: 105). Dalam penelitian kualitatif, peneliti berperan sebagai perencana, pelaksana, pengumpul data, analisis, penafsir data penelitian yang telah dilakukan (Moleong, 2001: 3).

Dalam penelitian ini, sumber data yang digunakan adalah: (1) Sumber Data Primer. Data primer adalah yaitu data yang langsung dikumpulkan oleh peneliti (atau petugas-petugasnya) dari sumber pertamanya (Suryabrata, 2014). 
Sedangkan menurut Lofland, sumber data utama dalam penelitian kualitatif ialah kata-kata, dan tindakan, selebihnya adalah data tambahan seperti dokumen dan lain-lain. Adapun narasumber data primer dalam penelitian ini adalah Kepala Sekolah dan Wakil Kepala Sekolah SMPN 9 Musi Banyuasin, Guru-Guru SMPN 9 Musi Banyuasin, tata usaha SMPN 9 Musi Banyuasin, peserta didik kelas VII dan VIII SMP Negeri 9 Kabupaten Musi Banyuasin; (2) Sumber Data Sekunder. Data sekunder yang digunakan meliputi sumber data yang diperoleh dengan cara membaca, mempelajari dan memahami melalui media lain yang bersumber dari literatur, internet, buku-buku, serta dokumen sekolah dan situs resmi pemerintah. Dalam pengumpulan data sehubungan dengan penelitian ini, penulis menggunakan metode-metode sebagai berikut: (a) Observasi. Menurut Arikunto (2002: 133), di dalam pengertian psikologi, observasi atau yang disebut pula dengan pengamatan, meliputi kegiatan pemuatan perhatian terhadap sesuatu obyek dengan menggunakan seluruh alat indera. Dalam hal ini, observasi dilakukan untuk mengetahui layanan bimbingan konseling dalam meningkatkan motivasi belajar peserta didik selama masa pandemi covid-19 di SMPN 9 Kabupaten Musi Banyuasin; (b) Wawancara. Menurut Moleong (2001: 186), wawancara atau interview adalah percakapan dengan maksud tertentu. Peneliti menggunakan metode wawancara atau interview untuk mengetahui data secara langsung dari sumbernya baik itu kepala SMP Negeri 9 Kabupaten Musi Banyuasin, guru, dan peserta didik; (c) Dokumentasi. Metode dokumentasi adalah teknik pengumpulan data dengan melihat sumber-sumber dokumen yang ada kaitanya dengan jenis data yang diperlukan (Arikunto, 2002: 131). Dalam penelitian ini, metode dokumentasi akan digunakan untukmemperoleh informasi yang akurat, sehingga akan menambah kevalidan hasil penelitian, diantaranya: Dokumentasi tentang sejarah singkat berdirinya SMP Negeri 9 Kabupaten Musi Banyuasin, Dokumentasi tentang Visi dan Misi SMP Negeri 9 Kabupaten Musi Banyuasin, Dokumentasi tentang Denah Lokasi SMP Negeri 9 Kabupaten Musi Banyuasin, Dokumentasi tentang Keadaan Peserta Didik SMP Negeri 9 Kabupaten Musi Banyuasin, Dokumentasi tentang Keadaan Guru SMP Negeri 9 Kabupaten Musi Banyuasin, Dokumentasi tentang Keadaan Sarana dan Prasarana 
SMP Negeri 9 Kabupaten Musi Banyuasin, Dokumentasi tentang struktur organisasi SMP Negeri 9 Kabupaten Musi Banyuasin.

Adapun tahap-tahap penelitian yang dilakukan antara lain: menguraikan tentang proses pelaksanaan penelitian mulai dari penelitian pendahuluan, pengembangan desain, penelitian lapangan hingga penelitian laporan, sehingga memberikan gambaran tentang keseluruhan perencanaan, pelaksanaan pengumpulan data, analisis dan penafsiran data hingga format penulisannya. Uji keabsahan data atau kepercayaan terhadap hasil penelitian kualitatif antara lain dilakukan pada perpanjangan pengamatan, peningkatan ketekunan dalam penelitian, triangulasi, diskusi dengan teman sejawat, dan analisis kasus negatif (Sugiyono, 2009). Teknik pemeriksaan keabsahan data pada penelitian yang penulis lakukan ini adalah dengan menggunakan triangulasi. Menurut Sugiyono (2009), triangulasi adalah pengecekan data dari berbagai sumber dengan berbagai cara, dan berbagai waktu. Triangulasi dalam pengujian kredibilitas ini diartikan sebagai pengecekan data dari berbagai sumber, cara dan waktu.

Data yang diperoleh tidak direalisasikan dalam bentuk angka tetapi data dalam bentuk uraian atau gambaran tentang kondisi obyek penelitian berkenaan dengan tema yang dikaji dalam penelitian ini. Untuk mendapatkan data yang lebih relevan dan urgen terhadap data yang telah dikumpulkan, maka peneliti menggunakan beberapa teknik yaitu paristen observation, yaitu mengadakan observasi secara terus menerus terhadap subyek yang diteliti guna memahami gejala lebih mendalam mengenai Layanan bimbingan konseling dalam peningkatan motivasi belajar peserta didik di SMP Negeri 9 Kabupaten Musi Banyuasin. Seluruh data yang diperoleh dari observasi, sementara wawancara maupun dokumentasi diambil dan dicatat secermat mungkin, kemudian dikumpulkan menjadi satu catatan lapangan. Kemudian semua data dianalisis secara kualitatif sehingga menghasilkan suatu gambaran. Dalam penelitian ini penulis menggunakan analisis data secara induksi.

\section{HASIL DAN PEMBAHASAN}

Berdasarkan hasil wawancara dan observasi yang telah dilakukan oleh peneliti tentang layanan bimbingan konseling dalam meningkatkan motivasi 
belajar peserta didik di SMP Negeri 9 Kabupaten Musi Banyuasin, maka diperoleh:

\section{a. Layanan Orientasi, Informasi dan Konsultasi.}

Menurut Prayitno (2012: 256), layanan informasi merupakan layanan yang diberikan oleh guru Bimbingan dan Konseling kepada peserta didik terkait dengan informasi-informasi yang ada di sekolah maupun luar sekolah. Informasi yang ada di sekolah, yakni mengenai tata cara atau aturan dalam sekolah dan kegiatankegiatan di sekolah, sedangkan informasi di luar sekolah terkait dengan kehidupan di masyarakat, isu-isu terkini tentang situasi sosial yang ada, informasi dunia kerja dan karir.

Berdasarkan hasil wawancara dengan Ibu Wakil Kepala Sekolah bidang Kurikulum Ibu Nurlaili, S.Pd mengenai manfaat yang dirasakan oleh peserta didik di SMP Negeri 9 Kabupaten Musi Banyuasin selama masa pandemi covid-19, diperoleh: "ya, layanan informasi sebagai layanan dasar bimbingan konseling telah dirasakan manfaatnya oleh peserta didik di SMPN 9 Kabupaten Musi Banyuasin sebelum dan selama masa pandemi covid-19". Hasil wawancara dengan Bapak Rudie Hartoko, S.Pd selaku wakil kepala sekolah bidang kesiswaan sekaligus guru matapelajaran IPA dan Seni Budaya menyatakan bahwa "Sebagai pendidik sekaligus orang tua peserta didik di sekolah, kita selalu mengarahkan dan memberikan informasi yang dibutuhkan oleh peserta didik, seperti peraturan sekolah, pembelajaran di sekolah sebelum dan selama pandemi covid-19 dan sebagainya, agar peserta didik bisa mengenali lingkungan sekolah, kami juga selaku pimpinan di SMP Negeri 9 Kabupaten Musi Banyuasin bertanggungjawab dan selalu memberikan informasi mengenai kelanjutan studi peserta didik setelah lulus dari SMP Negeri 9 Musi Banyuasin agar peserta didik mempunyai pandangan dan pilihan tentang dimana mereka akan melanjutkan studinya sesuai sekolah yang mereka inginkan".

Mengenai apakah layanan bimbingan konseling yang diberikan guru BK SMPN 9 Musi Banyuasin sudah dimanfaatkan dengan baik oleh peserta didik dan bagaimana antusiasme peserta didik terhadap layanan ini di masa pandemi covid19, Ibu Tuti Alawiyah, S.Pd.I (guru Pendidikan Agama Islam), menyatakan bahwa "layanan bimbingan konseling yang diberikan guru BK SMPN 9 Musi 
Banyuasin sangat dimanfaatkan dengan baik oleh peserta didik SMPN 9 Musi Banyuasin dan peserta didik sangat antusias dengan adanya layanan ini terlebih di masa pandemi covid-19". Peserta didik kelas VII.3 (YL) menyatakan bahwa "sebagai peserta didik baru, saya sangat terbantu dengan adanya layanan bimbingan konseling yang diberikan guru BK SMPN 9 Musi Banyuasin dan saya salah satu siswa yang memanfaatkan layanan ini karena saya membutuhkan solusi atas masalah yang saya hadapi, terlebih saya tidak memiliki ponsel pintar untuk mengikuti pembelajaran daring di SMPN 9 Musi Banyuasin”.

Adapun alokasi waktu yang diberikan oleh guru bimbingan konseling kepada peserta didik, PRU (VIII.2) menyatakan bahwa "hampir 24 jam dalam sehari ibu M menerima keluhan kami, dikarenakan bimbingan konseling dilakukan secara tatap muka dan daring (melalui pesan singkat SMS, chat whatsapp dan video call) sehingga murid-murid bebas kapan saja melaporkan keluhan-keluhan kami atas masalah yang kami hadapi”.

Hasil wawancara dengan Bapak Ahmad Siswoyo, S.Pd. (guru matapelajaran IPS), bahwa "guru bimbingan konseling SMPN 9 Musi Banyuasin berkoordinasi dengan guru-guru matapelajaran dan jajaran pimpinan SMPN 9 Musi Banyuasin telah mencari solusi atas masalah yang dihadapi peserta didik selama masa pandemi covid-19”.

Mengenai konsultasi yang dilakukan guru bimbingan konseling SMPN 9 Musi Banyuasin dengan orangtua/wali peserta didik serta guru-guru matapelajaran sebelum memberikan bantuan kepada peserta didik yang membutuhkan konseling selama masa pandemi covid-19, Ibu Heni Nauli, S.Pd. (guru Bahasa Indonesia), menyatakan bahwa "guru bimbingan konseling melakukan konsultasi terlebih dahulu dengan orangtua/wali peserta didik dan guru-guru matapelajaran sebelum memberikan bantuan kepada peserta didik selama masa pandemi covid-19”. Bapak Rudie Hartoko, S.Pd selaku wakil kepala sekolah bidang kesiswaan sekaligus guru matapelajaran IPA dan Seni Budaya menyatakan bahwa "layanan bimbingan konseling telah sesuai dengan kebijakan panduan operasional penyelenggaraan bimbingan konseling di SMPN 9 Musi Banyuasin pada masa pandemi covid-19”. 
Berdasarkan hasil observasi yang peneliti lakukan di SMP Negeri 9 Kabupaten Musi Banyuasin bahwa kepala sekolah, wakil kepala sekolah dan Guru Bimbingan Konseling memberikan informasi kepada peserta didik tentang lingkungannya, sumber-sumber belajar dan tidak lupa kepala sekolah dan guru bimbingan konseling memberikan informasi mengenai kelanjutan studi peserta didik agar mempunyai perencanaan dan memudahkan peserta didik dalam memilih dan membuat keputusan. Dari hasil wawancara dan observasi tersebut, maka dapat diambil kesimpulan bahwa Kepala Sekolah, Wakil Kepala Sekolah dan Guru Bimbingan Konseling telah memberikan informasi yang dibutuhkan oleh peserta didik agar peserta didik mempunyai pengetahuan yang baik tentang dirinya, lingkungannya, tentang sumber belajar, dan informasi mengenai kelanjutan studi agar peserta didik mempunyai rencana dan mengambil keputusan untuk masa depannya. Peserta didik memanfaatkan layanan bimbingan konseling di SMPN 9 Musi Banyuasin pada masa pandemi covid-19.

\section{b. Layanan Penempatan dan Penyaluran}

Layanan bimbingan memungkinkan peserta didik memperoleh penempatan dan penyaluran yang tepat, misalnya penempatan atau penyaluran selama pembelajaran daring, kelompok belajar dalam pembelajaran daring, jurusan, atau program studi, program pilihan, magang, kegiatan kulikuler atau ekstrakurikuler sesuai dengan potensi, bakat, dan minat serta kondisi pribadinya. Menurut Prayitno (2012: 256), "Layanan Penempatan dan Penyaluran merupakan layanan komunikatif antara guru Bimbingan dan Konseling dengan peserta didik sehubungan dengan minat, bakat, dan pemilihan karir yang berujung pada pada masa depan peserta didik".

Berdasarkan hasil wawancara dengan Wakil Kepala Sekolah bidang Kurikulum Ibu Nurlaili, S.Pd. menyatakan bahwa: "Saya bekerja sama dengan semua jajaran pimpinan SMP Negeri 9 Kabupaten Musi Banyuasin, guru Bimbingan Konseling, guru-guru, Pembina Eskul, pengurus Pramuka, dan untuk melihat potensi yang dimiliki oleh peserta didik, agar dapat dikembangkan sesuai potensi yang dimiliki”. Hal ini sesuai dengan pernyataan peserta didik kelas VIII.1 SA, bahwa: "Iya, biasanya saya dibantu dalam mengembangkan potensi saya. Seperti saya menyukai pramuka, bapak/ ibu guru selalu membantu saya dalam 
kepramukaan meskipun sekarang masih pandemi, kami tetap diberikan informasi yang sangat bermanfaat bagi kami semua".

\section{c. Layanan Pembelajaran}

Layanan bimbingan dan konseling memungkinkan peserta didik mengembangkan diri berkenaan dengan sikap dan kebiasaan belajar yang baik, materi belajar yang cocok dengan kecepatan dan kesulitan belajarnya, serta berbagai aspek tujuan dan kegiatan belajar lainnya, sesuai dengan perkembangan ilmu, teknologi, dan kesenian. Menurut Prayitno (2012: 256), "Layanan Bimbingan Belajar merupakan layanan yang diberikan oleh guru Bimbingan dan Konseling yang berkaitan dengan kegiatan belajar peserta didik".

Bapak Rudie Hartoko, S.Pd. selaku wakil kepala sekolah bidang kesiswaan menyatakan bahwa "Saya bekerja sama dengan kepala sekolah, wakil kepala sekolah bidang kurikulum, Pembina OSIS, wali kelas, dan guru mata pelajaran yang ikut membantu mengatasi masalah yang dihadapi oleh peserta didik selama masa belajar dari rumah (study from home), terutama pada masa pandemi covid-19 seperti sekarang ini, kami berkoordinasi dengan orang tua peserta didik yang lebih sering banyak waktu untuk membantu serta mendampingi permasalahan peserta didik dalam mengikuti pembelajaran dari rumah. Upaya yang bisa saya lakukan adalah kami memanggil Guru Bimbingan Konseling dan berdiskusi mengenai peserta didik yang mengalami kesulitan belajar dan mencari solusi atas permasalahan tersebut. Wakil kepala sekolah bidang kesiswaan, pembina OSIS, dan Guru bidang studi yang ikut berperan dalam pelayanan bimbingan konseling bekerjasama mendatangi rumah peserta didik agar kami mengetahui permasalahan pembelajaran daring dan luring selama masa pandemi covid-19 dan mencari solusi bersama agar permasalahan motivasi belajar peserta didik dapat teratasi. Kita tahu informasi tentang peserta didik dirumah melalui orang tua, bagaimana lingkungan sekitarnya dan sebagainya. Banyak peserta didik yang ditinggal orang tuanya bekerja ketika mengikuti pembelajaran daring sehingga banyak dari mereka tidak terpantau. Ada orang tua dirumah saja jarang mengontrol belajar peserta didik apalagi mereka yang tinggal dengan pakde, mbah dan lain sebagainya. Jadi kami bekerja sama dengan orang tua untuk membantu kesulitan belajar peserta didik”. Mengenai pendampingan oleh guru bimbingan 
konseling SMPN 9 Musi Banyuasin pada setiap peserta didik yang mempunyai masalah dalam pembelajaran selama masa pandemi covid-19, Ibu Wakil Kepala Sekolah bidang Kurikulum Ibu Nurlaili, S.Pd menyatakan bahwa "guru bimbingan konseling SMPN 9 Musi Banyuasin selalu memberikan pendampingan kepada setiap peserta didik yang mempunyai masalah dalam belajar selama masa pandemi covid-19”. Ibu Lies Nopriyani, S.Pd. (guru Bahasa Inggris), mengatakan bahwa "guru bimbingan konseling SMPN 9 Musi Banyuasin memberikan pendampingan kepada setiap peserta didik yang tidak memiliki smartphone selama pembelajaran daring di masa pandemi covid-19”. Begitupun Ibu Novalmi Achiriah, S.Pd. (guru Matematika), menyatakan bahwa "guru bimbingan konseling SMPN 9 Musi Banyuasin memberikan pendampingan kepada setiap peserta didik yang mengalami kesulitan memahami pelajaran matematika karena sulitnya memahami materi pembelajaran secara daring maupun luring selama masa pandemi covid-19”. Peserta didik NK (VII.3) menyatakan: "Guru bimbingan konseling beserta jajaran guru mendatangi beberapa rumah peserta didik yang mengalami kesulitan dalam pembelajaran daring dan luring, guru bertanya mengapa anda sulit dalam belajar, adakah kendala yang membuat anda sulit dalam belajar daring atau luring, dan meminta saya untuk mengutarakan apa yang menjadi kendala. Setelah itu guru bimbingan konseling menasehati saya dan membantu saya untuk mencari solusi pembelajaran daring dan luring yang diselenggarakan SMP Negeri 9 Kabupaten Musi Banyuasin selama masa pandemi covid-19”. Peserta didik YS (VII.2) mengatakan “Guru BK bertanya kepada saya, terkait dengan orang tua saya, tinggal dengan siapa, apa pekerjaan dirumah. Setelah itu guru bimbingan konseling menasehati saya untuk selalu giat dalam belajar, dan tidak membolos selama belajar daring atau luring”.

Mengenai apakah peserta didik hadir tepat waktu dalam pembelajaran daring/luring pada masa pandemi covid-19 dan apakah ada peserta didik yang hanya melakukan presensi selama pembelajaran daring dan tidak mengikuti pembelajaran ketika guru menyampaikan materi, Ibu Novalmi Achiriah, S.Pd. (guru Matematika) mengatakan "beberapa peserta didik ada yang melakukan presensi saat 30 menit pelajaran sudah dimulai, bahkan pernah ada yang mengisi daftar hadir ketika pembelajaran daring sudah usai, ada pula siswa yang tidak 
mengikuti pembelajaran daring ketika namanya dipanggil yang bersangkutan tidak merespon padahal siswa tersebut mengisi daftar hadir".

Ibu Lies Nopriyani, S.Pd. (guru Bahasa Inggris) menyatakan bahwa "beberapa peserta didik tidak mengerjakan tugas-tugas yang diberikan selama pembelajaran daring dan luring dilakukan, namun setelah guru BK mendatangi rumah peserta didik yang bersangkutan, peserta didik jadi lebih bertanggungjawab dalam menyelesaikan tugas-tugas yang diberikan guru-guru. Secara afektif, kognitif dan psikomotorik, kemampuan peserta didik menurun di awal pandemi, namun seiring pelayanan bimbingan konseling diberikan kepada peserta didik, motivasi belajar peserta didik menjadi meningkat secara signifikan, secara kognitif, afektif dan psikomotorik kemampuan peserta didik mengalami penigkatan di akhir semester".

\section{d. Layanan Konseling Perorangan}

Hasil wawancara dengan wakil kesiswaan Bapak Rudie Hartoko, S.Pd, bahwa: "Untuk umumnya masalah seperti habis bangun tidur mengisi presensi lalu tidur kembali, tidak mengikuti pembelajaran daring dengan benar, tapi tidak semua peserta didik melakukannya, hanya beberapa saja. Kami harus menangani kasus seperti ini, kepala sekolah, wakil kepala sekolah bidang kurikulum, dan perangkat sekolah harus mencari jalan keluarnya". Mengenai apakah guru bimbingan konseling SMPN 9 Musi Banyuasin telah memberikan layanan perencanaan individual yang bertujuan untuk membantu peserta didik agar memiliki pemahaman tentang diri dan lingkungannya dan mengkoordinasikan serta melakukan monitoring kegiatan peserta didik, Ibu Wakil Kepala Sekolah bidang Kurikulum Ibu Nurlaili, S.Pd menyatakan bahwa "guru bimbingan konseling SMPN 9 Musi Banyuasin telah memberikan layanan perencanaan individual untuk membantu peserta didik agar memiliki pemahaman tentang diri dan lingkungannya serta melakukan koordinasi dan monitoring kegiatan peserta didik selama masa pandemi covid-19”.

Berdasarkan fakta lapangan, dapat disimpulkan bahwa layanan bimbingan konseling dalam meningkatkan motivasi belajar peserta didik di SMP Negeri 9 Kabupaten Musi Banyuasin pada masa pandemi covid-19 dalam pelaksanaannya 
dapat dikatakan sudah baik sehingga dapat mendukung layanan bimbingan konseling dalam peningkatan motivasi belajar peserta didik.

\section{KESIMPULAN}

Berdasarkan data yang diperoleh melalui hasil dokumentasi, wawancara dan observasi, maka dapat disimpulkan bahwa: layanan bimbingan konseling dalam meningkatkan motivasi belajar di SMP Negeri 9 Kabupaten Musi Banyuasin selama masa pandemi covid-19 dalam pelaksanaannya sudah baik. Adapun jenis Layanan Bimbingan Konseling dalam Meningkatkan Motivasi Belajar Peserta Didik di SMP Negeri 9 Kabupaten Musi Banyuasin Pada Masa Pandemi Covid-19, yaitu: (a) Kepala sekolah, wakil kepala sekolah dan guru bimbingan konseling telah melaksanakan layanan informasi kepada peserta didik selama masa pandemi covid-19, seperti: informasi mengenai pengetahuan tentang lingkungannya, sumber-sumber belajar yang dapat diakses peserta didik selama masa pandemi covid-19, dan informasi mengenai kelanjutan studi agar peserta didik lebih mudah dalam membuat perencanaan akan masuk ke SMA atau SMK di masa pandemi covid-19; (b) Kepala Sekolah, wakil kepala sekolah, dan guru bimbingan konseling telah membantu peserta didik dalam mengembangkan potensi yang dimiliki peserta didik, adanya kerja sama antara guru ekstrakurikuler dengan guru bimbingan konseling dalam mengembangkan potensi peserta didik selama masa pandemi covid-19; (c) Guru bimbingan konseling memberikan bantuan kepada peserta didik yang mengalami kesulitan dalam belajar daring maupun luring di masa pandemi covid-19, dan berusaha mengembangkan perilaku belajar peserta didik yang baik di masa pandemi covid-19; (d) Kepala sekolah, wakil kepala sekolah dan guru bimbingan konseling selalu membantu peserta didik apabila peserta didik mengalami masalah, kepala sekolah dan guru bimbingan konseling bekerja sama dengan orang tua peserta didik dalam menangani kesulitan dalam belajar peserta didik selama masa pandemi covid-19, malas dalam belajar baik daring maupun luring, dengan cara bertanya kepada peserta didik dan memberikan solusi kepada peserta didik.

Kepala sekolah dan pihak-pihak yang terlibat dalam membuat kebijakan di sekolah harus selalu memonitor dan mengevaluasi proses pembelajaran daring dan 
luring di masa pandemi covid-19 guna membantu guru bimbingan konseling dan guru-guru dalam melaksanakan pembelajaran daring dan luring agar peserta didik termotivasi untuk belajar dan dapat dengan mudah mengikuti pembelajaran di masa pandemi covid-19. Kepala Sekolah harus dapat mengambil keputusan dengan cepat agar guru bimbingan konseling bekerjasama dengan guru-guru dapat mengatasi masalah belajar peserta didik selama masa pandemi covid-19, diperlukannya suatu sistem agar guru bimbingan konseling dapat terhubung langsung dengan peserta didik, terutama di masa pandemi covid-19 agar proses bimbingan konseling peserta didik dapat terlaksana dengan efektif dan efisien, peserta didik hendaknya mentaati peraturan sekolah meskipun pembelajaran masih dilakukan secara daring dan luring, untuk peneliti selanjutnya agar menjadi wawasan dan menjadi referensi untuk penelitian selanjutnya.

\section{DAFTAR PUSTAKA}

Arikunto, S. (2002). Prosedur Penelitian (Suatu Pendekatan dan Praktek) (V ed.). Jakarta: Rineka Cipta.

Awaliya, dkk. (2013). Bimbingan dan Konseling. Semarang: UNNES Press.

Kountoro, Ronny (2004). Metode Penelitian untuk Penulisan Skripsi dan Tesis. Jakarta: PT PPM.

Moleong, Lexy. J. (2001). Metodologi Penelitian Kualitatif. Bandung: Remaja Rosdakarya.

Prayitno. (2012). Jenis Layanan dan Kegiatan Pendukung Konseling. Padang: UNP.

Raco, J. R. (2010). Metode Penelitian Kualitatif, Jenis Karakteristik dan Keunggulannya. Jakarta: Grasindo.

Sardiman. (2012). Interaksi dan Motivasi Belajar Mengajar. Jakarta: PT Raja Grafindo Persada.

Sugiyono. (2009). Metode Penelitian Kuantitatif Kualitatif $R \& D$ (VIII ed.). Bandung: Alfabeta.

Suryabrata, S. (2014). Metedologi Penelitian (II ed.). Jakarta: Raja Grafindo Persada. 